\title{
Factitious Disorder Presenting with Refractory Enterocutaneous Fistula that Underwent 7 Surgeries
}

\author{
Di Zhao Qiyi Chen Ning Li
}

Department of Colorectal Disease, The No.10 People's Hospital of Shanghai, Shanghai, China

\section{Keywords}

Enterocutaneous fistula · Appendectomy · Factitious disorder

\begin{abstract}
The formation of a post-appendicectomy fistula is rare but devastating. Major etiological factors include leakage from the appendiceal stump, neoplasm of the appendix and/or cecum, infection, inflammatory bowel disease, and distal obstruction. The management of enterocutaneous fistula involves enteral nutrition, drainage, antibiotic coverage, as well as surgical excision and segmental resection of the involved bowel. Here we present a case where a young female suffered from refractory enterocutaneous fistula after appendicectomy. Despite extensive treatments, her symptoms persisted and contradicted with objective test results. Therefore, a diagnosis of factitious disorder was suspected. After questioning, she finally admitted to having applied feces to her wound to fake fistula. It was estimated that the lifetime prevalence of factitious disorder in the general population was $0.1 \%$, which warrants the awareness of clinicians.




\section{Case Reports in Gastroenterology}

Case Rep Gastroenterol 2020;14:291-298

DOI: $10.1159 / 000506936$

(c) 2020 The Author(s). Published by S. Karger AG, Basel www.karger.com/crg

Zhao et al.: Factitious Disorder with Enterocutaneous Fistula that Underwent 7 Surgeries

\section{Introduction}

Appendectomy is amongst the most common general surgical procedures performed. One critical part of this procedure is effective closure of the appendix stump to prevent catastrophic intra-abdominal complications from a fecal leak into the abdominal cavity. Prolonged intrabdominal infection can lead to enterocutaneous fistula, chronic bowel obstruction, sepsis, and even death [1]. The standard treatment includes percutaneous drainage, enteral nutritional support, wound dressings, and antibiotics. Some refractory fistulas may need surgical repairment [2]. Here we present a case where a young female suffered from purulent and feces-containing exudate from incision after appendectomy. She underwent adequate drainage, nutritional support, and multiple unsuccessful surgeries before we suspected a factitious disease. Our purpose is therefore to familiarize clinicians with the diagnosis and treatment of this rare cause of enterocutaneous fistula.

\section{Case Report}

A 27-year-old nurse was admitted to our department in November 2018 with complaints of persistent abdominal pain in the right lower quadrant and constant purulent secretion from incision of appendectomy more than 2 years previously. She also reported intermittent fever, flatulence, and cessation of defecation.

Review of the patient's history revealed that she was diagnosed with acute appendicitis in August 2016 and underwent appendectomy in a local hospital. The patient complained about poor recovery of the wound as well as intermittent fever and persistent abdominal pain. After two unsuccessful debridement operations she was transferred to a tertiary hospital in Beijing. In suspicion of appendix stump fistula, an open exploration was thus performed in August 2017. Moderate adhesion was found between the greater omentum and the terminal ileum; no definite fistula or other lesion was detected during the operation. An end-ileum right-ascending colon anastomosis was performed; however, her symptoms persisted. After two more debridement operations in September 2018, she gradually developed symptoms of bowel obstruction, including nausea, vomiting, flatulence, and cessation of defection. Right before her transfer to our department, a colon endoscopy was performed, and a clean anastomosis was identified.

Upon administration to our hospital, the patient was on total parenteral nutrition and complained of severe abdominal pain that only responded to venous tramadol. Physical examination revealed slightly below average nutrition state, normal body temperature, incision on the right lower quadrant with purulent, feces-containing exudate, rebound tenderness in the right lower quadrant, and weak bowel sounds. Immediate complete blood count, basic metabolic panel, liver, and renal function panel were all within normal range. Abdominal CT scan revealed exudation around the operation area and gas accumulation within the abdominal wall. Contrast agent was injected via the fistula opening but only ended within the abdominal wall (Fig. 1). Oral administration of diatrizoate indicated delayed gastric emptying and duodenal stasis.

A sump drainage tube was placed along the original incision; the drainage was murky dark brown (Fig. 2). Considering the duodenal stasis might explain her distention and 


\section{Case Reports in Gastroenterology}

Case Rep Gastroenterol 2020;14:291-298

DOI: $10.1159 / 000506936$

(c) 2020 The Author(s). Published by S. Karger AG, Base www.karger.com/crg

Zhao et al.: Factitious Disorder with Enterocutaneous Fistula that Underwent 7 Surgeries

reluctance to eat, a nasal-jejunal feeding tube was placed at the bedside, nil per os, and enteral nutrition was advised. One week of continuous rinse and drainage did not help relieve her symptoms, thus an exploration was again ordered on December 1,2018, via the original incision. No definite fistula opening was identified aside from moderate adhesion resulting from preceding operations. A sump drainage tube was placed with in the right colonic sulcus to provide assertive drainage within the abdominal cavity, and no bowel segment was resected. After weeks of continuous rinse and drain $(2,000 \mathrm{~mL}$ of natural saline per day), there was no signs of her intraabdominal drainage turning clear. Despite repetitive attempts, the patient failed to tolerate enteral nutrition and still relied on total parenteral nutrition. Her symptoms of fever and abdominal pain also persisted.

A deeper look into her possible pathophysiology was called forth. Her previous endoscopy and CT scan had ruled out the possibility of inflammatory bowel disease. Her auto-antibody panel did not support auto-immune- mediated enteritis. Other possible factors that might hinder the recovery of fistula including distal obstruction or stricture, active inflammation, malignancy, radiation, foreign body, malnutrition, or sepsis were expeditiously eliminated. An empirical hydrocortisone of $200 \mathrm{mg}$ daily was given but was stopped shortly after the patient developed hematemesis. Immediate esophagogastroduodenoscopy did not show any bleeding point (Fig. 3).

Her refractory fistula and undetermined underling disease prompted us to perform a second midline incision exploration on January 4, 2019. Despite mild adhesion, this thorough inspection revealed no abscess, inflammation, or fistula.

The fact that her symptoms contradicted at greatest length with what was revealed in the exploratory laparotomy as well as her unusual long stay in the women's room every time before we inspected her wound made us suspect a factitious disease. Vigorous questioning finally made her admit that she had voluntarily applied feces to her incision wound to fake enterocutaneous fistula. The complete situation was discussed with her close relatives and she was monitored intensively on a 24-h basis. Her recovery from the surgery was uneventful and she was discharged 10 days later.

The patient's profession (nursing) and familiarity with hospital routines allowed her to claim all the symptoms related to enterocutaneous fistula, bowel obstruction, and hematemesis. Because her deceptive behaviors were not related to obvious external rewards and could not be better explained by other mental disorders, the diagnosis of factitious disorder imposed on self (previously referred to as Munchausen syndrome) was made. She was therefore sent for psychological consultation. After 1 year of follow-up, no further abdominal discomfort was reported by this patient.

\section{Discussion/Conclusion}

It took more than 2 years and 7 surgeries ( 4 debridement operations and 3 exploratory laparotomies) to establish her diagnosis, which has never been reported elsewhere before. A diagnosis of factitious disorder imposed on self requires the patient to falsify symptoms and signs that deceive clinicians in the absence of obvious external rewards. To date, this behavior cannot be better explained by other mental disorders [3]. Her experience of training and working in a hospital setting prepared her to simulate post-appendicectomy enterocutaneous 


\section{Case Reports in Gastroenterology}

Case Rep Gastroenterol 2020;14:291-298

(c) 2020 The Author(s). Published by S. Karger AG, Base www.karger.com/crg

Zhao et al.: Factitious Disorder with Enterocutaneous Fistula that Underwent 7 Surgeries

fistula, deceiving gastroenterologists from 2 tertiary hospitals. She inclusively met all the risk factors of factitious disorder established by previous studies which included female, unmarried, and healthcare workers [4].

A number of techniques were deployed by this patient to disrupt the clinician's standard practices aside from deliberately applying feces to her incision wound. Her other attempts included hiding the methylene blue ampoule and adding the residue dye to the drainage vessel to manipulate the test result, as well as drawing blood from her peripherally inserted central catheter and then injecting blood into her nasal-jejunal feeding tube to fake hematemesis. Other efforts might have included feigning loss of consciousness, warming the thermometer using a heat source, and contamination of drainage vessel with food residues. She exploited our fear of missing rare life-threatening diseases such as Crohn's disease or vasculitis and played into the fascination of doctors from tertiary hospitals with regard to solving a medical mystery.

The diagnosis of factitious illness is certainly not well known by gastroenterology personnel and its evocation is not routinely evoked. The ample experience of our center as to the treatment of fistula postponed her exploratory laparotomy albeit her poor response to nonsurgical treatments. We also failed to notice her stable nutrition status which was rare in genuine gastrointestinal failure patients for 2 years. Consultation with the psychological department was made twice for her sleeping disorder. However, because the complete clinical data was not provided to the psychiatrist, no definite diagnosis was made.

Had a diagnosis of factitious disorder be made earlier, the patient's self-disabling behaviors as well as iatrogenic complications arising from unnecessary tests and treatments (multiple surgeries in this case) would have been prevented. Deaths may also occur in up to $20 \%$ of these patients because they might underestimate the lethality of their maneuvers [5]. Family members might initiate a lawsuit about malpractice as a result. The moment we suspected a factitious disease, we discussed the complete situation with her family who later agreed with the final diagnosis. Therefore, any litigation about malpractice was avoided.

Thorough interview with her close relatives revealed she was born into a divorced family with an absent mother and father. She was raised by her aunt and uncle and competed for attention with her cousins. The urge to receive affection is the most probable motivation for her to adopt the sick role. Her symptoms evolved slowly from abdominal pain, which is proven to be the most common falsified symptom of factitious disorder [4]. The chronology of her symptoms is summarized in Table 1.

The development of fistula after bowel resection and anastomosis can be devastating. Immediate drainage and establishment of enteral nutrition can lead to spontaneous healing of fistula [6]. Multiple futile attempts of standard treatments, contradiction of symptoms, and objective tests should elicit the awareness of factitious disease. It was estimated that the lifetime prevalence of factitious disorder in the general population was $0.1 \%$ which warrants the awareness of clinicians [7]. For patients diagnosed with factitious disease imposed on self, psychotherapy is considered the first-line treatment compared with pharmacotherapy and observation [8]. Disease generally presents as intermittent episodes, and full recovery is rare [9]. The persistent nature of factitious behaviors can lead to significant morbidity and mortality [4]. 


\section{Case Reports in Gastroenterology}

Case Rep Gastroenterol 2020;14:291-298

DOI: $10.1159 / 00050693$

(c) 2020 The Author(s). Published by S. Karger AG, Base www.karger.com/crg

Zhao et al.: Factitious Disorder with Enterocutaneous Fistula that Underwent 7 Surgeries

\section{Statement of Ethics}

Informed consent was obtained for this case report. Ethics approval was not needed for this paper.

\section{Disclosure Statement}

The authors have no conflicts of interest to declare.

\section{Funding Sources}

This work was supported by grants from the National Natural Science Foundation of China (No. 81700480).

\section{Author Contributions}

Di Zhao and Qiyi Chen performed data acquisition and drafted the manuscript. Ning Li supervised and provided critical revision of the manuscript. All authors read and approved the final manuscript.

\section{References}

1 Montravers P, Dupont H, Leone M, Constantin JM, Mertes PM, Laterre PF, et al.; Société française d'anesthésie et de réanimation (Sfar); Société de réanimation de langue française (SRLF); Société de pathologie infectieuse de langue française (SPILF); Association française de chirurgie (AFC); Société française de chirurgie digestive (SFCD). Guidelines for management of intra-abdominal infections. Anaesth Crit Care Pain Med. 2015 Apr;34(2):117-30.

2 Quinn M, Falconer S, McKee RF. Management of enterocutaneous fistula: outcomes in 276 patients. World J Surg. 2017 Oct;41(10):2502-11.

3 Huffman JC, Stern TA. The diagnosis and treatment of Munchausen's syndrome. Gen Hosp Psychiatry. 2003 Sep-Oct;25(5):358-63.

4 Bass C, Halligan P. Factitious disorders and malingering: challenges for clinical assessment and management. Lancet. 2014 Apr;383(9926):1422-32.

5 Eisendrath SJ, McNiel DE. Factitious physical disorders, litigation, and mortality. Psychosomatics. 2004 JulAug;45(4):350-3.

6 Ashkenazi I, Turégano-Fuentes F, Olsha O, Alfici R. Treatment options in gastrointestinal cutaneous fistulas. Surg J (N Y). 2017 Mar;3(1):e25-31.

7 Faravelli C, Abrardi L, Bartolozzi D, Cecchi C, Cosci F, D’Adamo D, et al. The Sesto Fiorentino study: background, methods and preliminary results. Lifetime prevalence of psychiatric disorders in an Italian community sample using clinical interviewers. Psychother Psychosom. 2004 Jul-Aug;73(4):216-25.

8 Dhar SS. Deception syndromes: factitious disorders and malingering. In: Levenson JL, editor. The American Psychiatric Publishing textbook of psychosomatic medicine: psychiatric care of the medically ill. 2nd ed. Washington (DC): American Psychiatric Publishing; 2011.

9 Bass C, Taylor M. Recovery from chronic factitious disorder (Munchausen's syndrome): a personal account. Pers Ment Health. 2013;7(1):80-3. 


\section{Case Reports in Gastroenterology}

\begin{tabular}{l|l}
\hline Case Rep Gastroenterol 2020;14:291-298 \\
\hline DOI: 10.1159/000506936 & $\begin{array}{l}\text { (c 2020 The Author(s). Published by S. Karger AG, Basel } \\
\text { www.karger.com/crg }\end{array}$ \\
\hline
\end{tabular}

Zhao et al.: Factitious Disorder with Enterocutaneous Fistula that Underwent 7 Surgeries

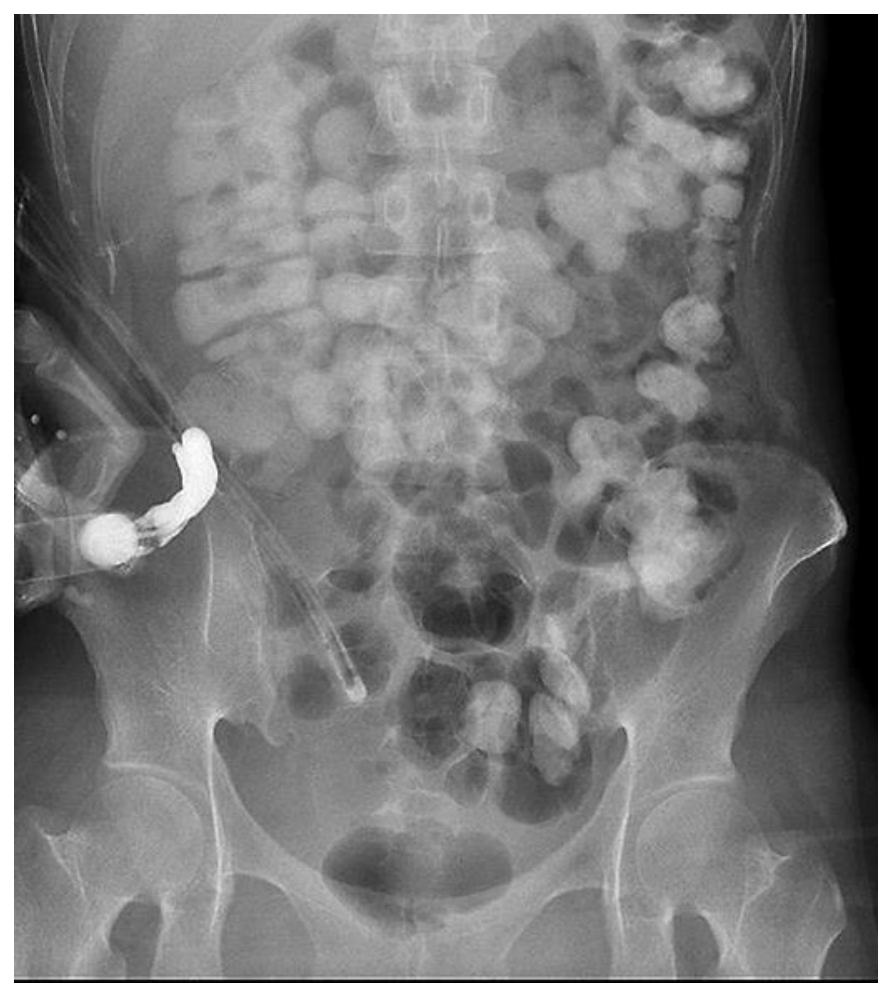

Fig. 1. Sinogram demonstrating administration of the diatrizoate via the fistula opening.

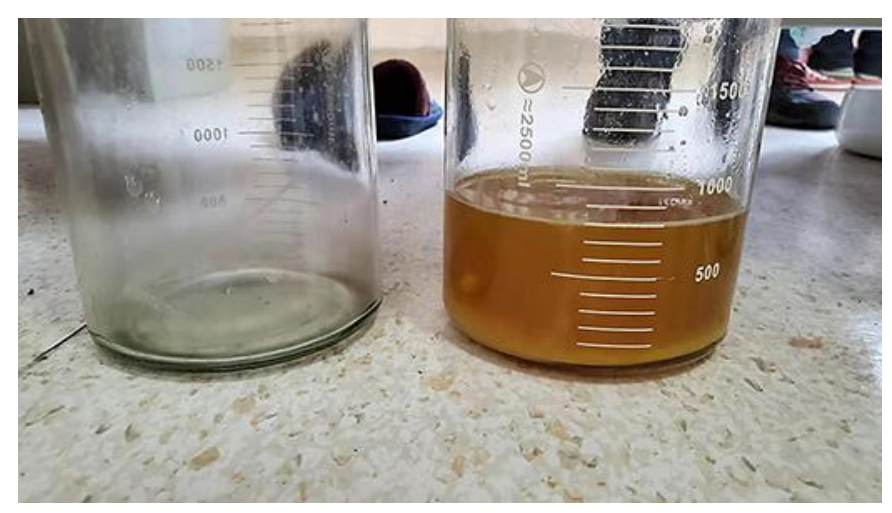

Fig. 2. Drainage from the patient's sump drainage tube. 


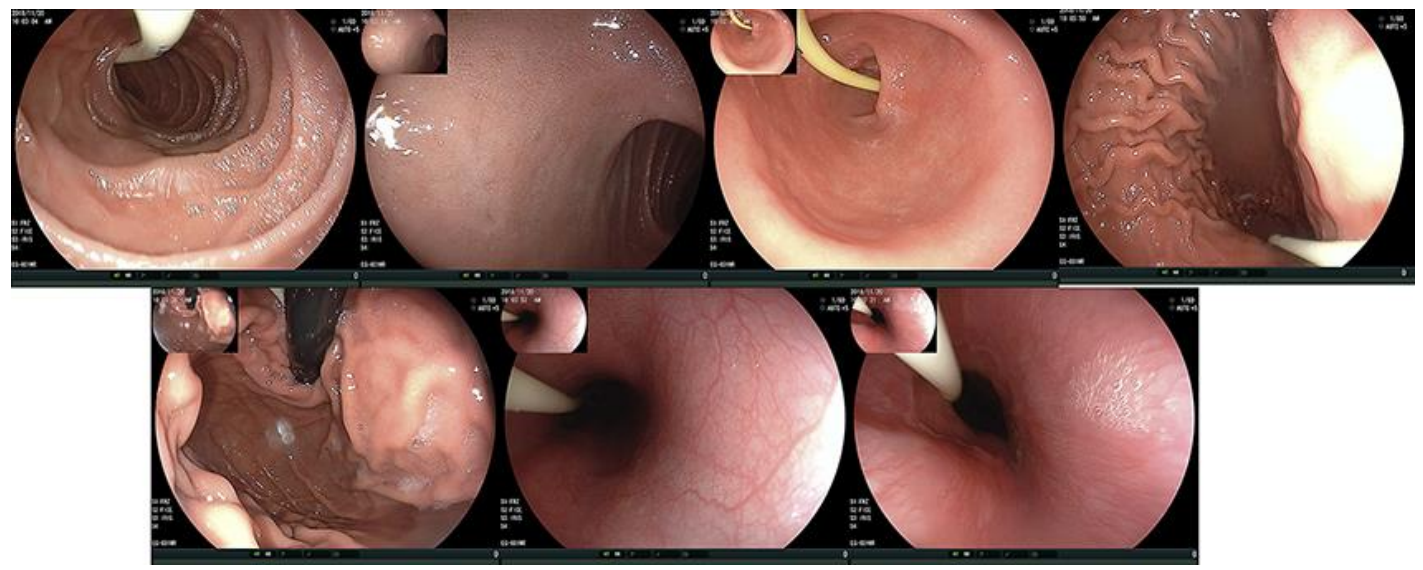

Fig. 3. Immediate esophagogastroduodenoscopy after the incidence of hematemesis did not show any bleeding point. 


\section{Case Reports in Gastroenterology}

\begin{tabular}{l|l}
\hline Case Rep Gastroenterol 2020;14:291-298 \\
\hline DOI: 10.1159/000506936 & $\begin{array}{l}\text { @ 2020 The Author(s). Published by S. Karger AG, Basel } \\
\text { www.karger.com/crg }\end{array}$ \\
\hline
\end{tabular}

Zhao et al.: Factitious Disorder with Enterocutaneous Fistula that Underwent 7 Surgeries

Table 1. The chronology of the patient's symptoms

\begin{tabular}{|c|c|c|c|c|c|}
\hline $\begin{array}{l}\text { Year } \\
\text { (age, years) }\end{array}$ & Assertions & Diagnosis & Tests & Treatments & $\begin{array}{l}\text { Possible } \\
\text { invocation }\end{array}$ \\
\hline $\begin{array}{l}2010 \\
(19)\end{array}$ & Oliguria & IgA nephropathy & Biopsy refused & $\begin{array}{l}\text { Dipyridamole, } \\
\text { furosemide, and } \\
\text { spironolactone }\end{array}$ & $\begin{array}{l}\text { Failed national col- } \\
\text { lege entrance ex- } \\
\text { amination }\end{array}$ \\
\hline $\begin{array}{l}2016 \\
(25)\end{array}$ & Abdominal pain & Appendicitis & NA & Appendicectomy & Boyfriend left her \\
\hline $\begin{array}{l}2016 \\
(25) \\
\end{array}$ & $\begin{array}{l}\text { Purulent exudates } \\
\text { from wound }\end{array}$ & $\begin{array}{l}\text { Appendix stump insuffi- } \\
\text { ciency }\end{array}$ & NA & 2 debridements & Grandmother ill \\
\hline $\begin{array}{l}2017 \\
(26)\end{array}$ & $\begin{array}{l}\text { Purulent and fecal } \\
\text { exudates from wound, fever, } \\
\text { abdominal pain }\end{array}$ & $\begin{array}{l}\text { Enterocutaneous } \\
\text { r, fistula }\end{array}$ & $\begin{array}{l}\text { Methylene blue } \\
\text { test }\end{array}$ & $\begin{array}{l}\text { An exploration and a deb- } \\
\text { ridement. }\end{array}$ & \\
\hline $\begin{array}{l}2018 \\
(27)\end{array}$ & $\begin{array}{l}\text { Nausea, vomiting, } \\
\text { flatulence, and cessation } \\
\text { of defection }\end{array}$ & Bowel obstruction & $\begin{array}{l}\text { CT scan and } \\
\text { colonoscopy }\end{array}$ & $\begin{array}{l}\text { Total parental } \\
\text { nutrition }\end{array}$ & \\
\hline $\begin{array}{l}2018 \\
(27)\end{array}$ & Loss of consciousness & $\begin{array}{l}\text { Seizure secondary to } \\
\text { dyshomeostasis }\end{array}$ & $\begin{array}{l}\text { MRI and 24-h } \\
\text { electroencephal- } \\
\text { ography }\end{array}$ & Bed rest & $\begin{array}{l}\text { Double-balloon en- } \\
\text { teroscopy ordered } \\
\text { for her }\end{array}$ \\
\hline $\begin{array}{l}2018 \\
(27)\end{array}$ & Dyspnea & $\begin{array}{l}\text { Pneumothorax } \\
\text { secondary to intrave- } \\
\text { nous cannula } \\
\text { implementation }\end{array}$ & $\begin{array}{l}\text { ABG and chest } \\
\text { X-ray }\end{array}$ & Oxygen therapy & $\begin{array}{l}\text { Midline incision ex- } \\
\text { ploration ordered } \\
\text { for her }\end{array}$ \\
\hline $\begin{array}{l}2018 \\
(27)\end{array}$ & $\begin{array}{l}\text { Blood in jejunum decom- } \\
\text { pression tube }\end{array}$ & Hematemesis & $\begin{array}{l}\text { Esophagogastro-duo- } \\
\text { denoscopy }\end{array}$ & $\begin{array}{l}\text { Stop hydrocortisone, } \\
\text { proton pump inhibitor }\end{array}$ & $\begin{array}{l}\text { Hydrocortisone } \\
\text { therapy }\end{array}$ \\
\hline
\end{tabular}

